\title{
Public's Knowledge, Attitude and Practices regarding COVID-19 Pandemic in Al Gharbia Governorate, Egypt
}

\author{
${ }^{1}$ Samira E. El Mezayen and ${ }^{2}$, Entisar Abo Elghite Elhossiny Elkazeh. \\ ${ }^{1}$ Lecturer in Community Health Nursing, Faculty of Nursing, Tanta University, Egypt. \\ ${ }^{2}$ Assistant professor of Community Health Nursing, Faculty of Nursing, Tanta University, \\ Egypt
}

\section{Abstract}

Background: Pandemic outbreak of highly contagious coronavirus (COVID-19) became a major threat to our physical and mental health due to the rapid spreading and related countermeasures particularly lockdowns. Population commitment to preventive measures of COVID-19 and political decisions taken depending on their sufficient knowledge and positive attitude about this disease. Aim: This study was conducted to assess public knowledge, attitude and practice regarding COVID-19 pandemic in Al Gharbia Governorate, Egypt. Design and Setting: Cross-sectional study was used among the general population at $\mathrm{Al}$ Gharbia Governorate Egypt, from April 18 until May 18, 2020. Sample: 526 participants whom complete the online survey at Al Gharbia Governorate Egypt. Tools: The online survey questionnaire was developed by the researchers. It consisted of four parts; socio-demographic data, a COVID-19 knowledge, attitude and reported practices questionnaire. Results: This study was revealed that the majority $(89.1 \%)$ of the studied sample had good knowledge. TV was the commonest source $(77 \%)$ followed by social media $(67.10 \%)$ for this knowledge. While, half (50\%) of them had reported poor practices regarding COVID-19. Conclusion and Recommendation: Our study showed that in spite of the respondents have exhibited good knowledge, positive attitude but they reported poor practices regarding covid-19 during the pandemic. So, we recommended that a health educational program should directed to high risk groups it will be more effective in prevention and control of COVID- 19 and all public should maintain commitment of precautionary measures.

Key words: COVID-19, Egypt، Community Health Nursing, Knowledge, Attitude, and Practices. 


\section{Introduction}

The World Health Organization (WHO) declared a global public health emergency against the outbreak of novel coronavirus disease (COVID-19), and since then has rapidly achieved a pandemic status $(1,2)$. Over 28637952 cases of COVID-19 and 917417 deaths have been reported worldwide as of $13^{\text {th }}$ September 2020 , by WHO including cases in over 75 lowincome and middle-income countries ${ }^{(3)}$. In Egypt, on $14^{\text {th }}$ September 2020, the Ministry of Health and Population confirmed a total of 101,009 confirmed cases, 84,161 recovered /and were discharged from Isolation and quarantine hospitals, and 5,648 death cases in the country from 28 Governorates ${ }^{(4)}$.

Sharp increases in COVID-19 caseloads will overwhelm health systems in countries already facing shortages of health workers and supplies. With millions of lives at stake, decisive action must be taken now to blunt the impact of the pandemic in countries likely to be hit the hardest ${ }^{(5)}$. The typical symptoms of COVID-19 have been identified as fever, dry cough, fatigue, myalgia, shortness of breath, and dyspnea $(6,7)$. Available evidence has shown that the virus spreads from human-to-human, mainly through respiratory droplets and body contacts ${ }^{(7,8)}$. Contact with contaminated surfaces, hands, and touching of faces-eye-nose-mouth are predominant ways to get exposed to the infected droplets ${ }^{(9)}$.

The elderly and patients with chronic diseases are more likely to be infected and are additionally more prone to serious complications, which may be associated with acute respiratory distress syndrome (ARDS) and cytokine storm ${ }^{(10)}$. Until now, there is no proved treatment or vaccination against COVID-19. Commitment of preventive measures are the primary intervention to minimize the spread of the virus in both health care settings and the community ${ }^{(11)}$.

Community health nurse $(\mathrm{CHN})$ play a pivotal role in reducing the devastating impact of COVID-19 by being known and trusted health professional who explain and reinforce broad preventive messages of this disease for all public. So assessing knowledge, attitudes and practices about COVID- 19 among public consider an important role of $\mathrm{CHN}$ in detecting a community's readiness to accept behavioral change measures from health authorities, provide better insight to address knowledge about the disease and the development of preventive measures, health promotion programs and help government in decisions taken (12-14). 
Hence, this study aimed to assess public knowledge, attitude and practice regarding COVID-19 pandemic in $\mathrm{Al}$ Gharbia governorate, Egypt.

\section{Research question}

What is the level of public' knowledge, attitude and practices about COVID-19?

\section{Subjects and Method}

\section{Study Design \& setting}

Cross-sectional study was used among the general population of $\mathrm{Al}$ Gharbia Governorate, Egypt.

\section{Sampling}

According to Egyptian Central Agency for Public Mobilization and Statistics the latest $\mathrm{Al}$ Gharbia governorate census is $5,237,753$ population (15). The representative target sample size needed, to achieve the study objectives and enough statistical power, was calculated with a sample size calculator ${ }^{(16)}$. The sample size calculator using a margin of error of $5 \%$, a confidence level of $95 \%$, a $50 \%$ response distribution, and 5,237,753 people arrived at 385 participants of internet users from all population in all centers of Al Gharbia governorate. Which increased to 526 to increase validity of result.

\section{Study Tool}

The online survey questionnaire was developed by the researchers based on review of current literature $\left.{ }^{(6-9,}, 17\right)$. It consists of four parts: -
Part one: - Socio-demographic data: which includes age, gender, marital status, education, occupation, family income, residence and source of their information.

Part two: - COVID-19 knowledge questionnaire: which includes 14 questions (1 regarding not previously diagnosed as a disease in humans, 4 regarding clinical presentations, 3 regarding mode of transmission, 3 regarding high risk group and 3 regarding treatment and preventive measures). Correct answers take one, incorrect answers and don't know take zero. The total knowledge scores of the studied participants regarding COVID-19 were 14, and classified into three categories as follows:

- Good knowledge: $>70 \%$ of the total score (More than 10).

- Fair knowledge: $\quad>50 \%-70 \%$ of the total score (from 8 to 9).

- Poor knowledge: $\leq 50 \%$ of the total score (less than and an equal to 7).

\section{Part three: - COVID-19 attitude} questionnaire: which includes 10 questions. A three -point Likert scale was assigned to all questions (agree, uncertain and disagree) coded from one to three, as: agree $=3$ uncertain $=2$ disagree $=1$.

Part four: - The study participants' reported practices: which include 10 questions. Done practices take one and not 
done take zero. The total reported practices scores of the studied participants regarding COVID-19 were 10, and classified into three categories as follows:

- Good practices: $>70 \%$ of the total score (More than 8).

- Average practices: $>50 \%-70 \%$ of the total score (from 6 to 7 ).

- Poor practices: $\leq 50 \%$ of the total score (less than and an equal to 5).

\section{Method}

\section{Validity and reliability}

The developed tool was submitted to five experts in the field of nursing and medicine for testing the face and content validity. The experts' questionnaires sheet used four points Likert scale ranging from strongly relevant score (4) to strongly not relevant score (1). Validity of the questionnaires based on experts' opinions were calculated and found to be $=(97.9 \%)$. The Cronbach's alpha coefficient of the knowledge, practices and attitude questionnaire were (0.96, 0.85 and 0.72) in our sample, indicating acceptable internal consistency ${ }^{(18)}$.

\section{Pilot study}

A pilot study was conducted on (20) internet usages to test the tools for its clarity, organization, applicability and to determine the length of time needed to collect the data. The necessary modifications were done. Those participants were excluded from the study samples.

\section{Data Collection}

Started from April 18, to May 18, 2020. During outbreak stage (The week immediately after the total prohibition of the first village that was have eight patients who confirmed diagnosis with novel corona virus (COIVD-19) (El hayatem) in Al Garbia Governorate. Data were collected online, via a self-reported questionnaire, using google form given the high internet usage among general population of all centers (Tanta, El Mehalla El Kopra، Qotor, El Santa, Zefta, Kafr ElZayeat, Basuon, and Samanod) at the Al Gharbia governorate, Egypt, a link of the survey was distributed to respondents, via Facebook and WhatsApp groups. They were invited to complete and submit the form.

\section{Ethical Considerations}

Respondents' anonymity and confidentiality were ensured. On the first page of the online questionnaire, respondents were clearly informed about the background and objectives of the study. The submission of the answered survey was considered as consent to participate in the study.

\section{Statistical Analysis}

The collected data was organized, tabulated and statistically analyzed using 
Statistical Package for the Social Sciences (SPSS) software, version 25. Frequencies of correct knowledge answers and various attitudes and practices were described. Correlation between variables was evaluated using Pearson's correlation coefficient. Significance was adopted at $\mathrm{P}<0.05$ for interpretation of results of tests of significance.

\section{Results}

Table (1): - Socio - demographic characteristics of studied participants. It shows that their age ranged from $20-58$ years with mean $36.42 \pm 9.91$ years. Regarding the sex more than half $(55.7 \%)$ of them were female and slightly less than one half $(52.1 \%)$ were married. In relation to education one third and more than one quarter (34.4 and 28.9) were have university and secondary\& technical education. As regards to occupation slightly less than three fifth $(36.9 \%$ and $18.4 \%$ ) were employees and have skilled work compared with about one third (32.3\%) not worked.in relation to family income about two fifth (38.4\% and $43.7 \%)$ of them mentioned that the income was not sufficient and had just sufficient in addition to, slightly less than three quarters $(70.9 \%)$ of them were from rural areas.

Table (2): Distribution of the studied participants according to their knowledge regarding COVID-19. It shows that slightly more than two fifth $(42.8 \%)$ of the study participants stated that COVID-19 was not previously diagnosed as a disease in humans, versus slightly more than one third $(35.2 \%)$ of them did not know. Regarding knowledge about signs and symptoms, the majority $(89.7 \%, 88.4 \%, 89.2 \%$ and $84.0 \%)$ stated that a very high temperature (fever), dry cough, difficulty breathing or shortness of breath, and general weakness were the signs and symptoms of COVID-19 respectively.

In relation to mode of transmission, the majority $(88.4 \%, 89.7 \%$ and $88.2 \%)$ of them mentioned that droplets from the patient during coughing or sneezing, touching objects or surfaces contaminated with the virus and direct contact with the infected person were common modes of transmission of COVID-19 respectively. Also, the majority $(85.4 \%, 77.0 \%$ and $87.5 \%$ ) respectively of the participants knew that people suffering from chronic diseases as diabetes, heart diseases, blood pressure, pregnant women and elderly people were more susceptible to infection respectively. Knowledge about the prevention and treatment was high among the participants, as three quarters $(75.7 \%)$ knew that COVID-19 had no treatment, while the majority ( $88.4 \%$ and 86.1$)$ of them realized that it can be prevented by 
isolation of patients and contacts respectively.

Figure (1): Distribution of the studied participants according to their total knowledge score regarding COVID-19. It was found that majority $(86.10 \%)$ of the studied sample had good knowledge and only $11.0 \%$ of them had poor knowledge.

Figure (2): Distribution of the studied participants according to their various sources of information regarding COVID-19. TV was the commonest source $(77 \%)$ followed by social media (67.10\%), internet (48.7\%), and Ministry of Health (44.7\%).

Table (3): Distribution of the studied participants according to their reported practices regarding COVID 19. The majority $(79.3 \%, 83.8 \%, 87.1 \%, 79.7 \%$, $87.6 \%, 84.4 \% \& 81.0 \%$ ) of participants reported that they staying at home, cover mouth and nose during sneezing and cough, washing hands frequently for 20 second, avoidance overcrowded places, disinfecting surfaces inside the home, eating fresh fruits and vegetables and drinking plenty of water and warm liquids, respectively. While, less than three quarters $(72.8 \%)$ of them reported sleep enough hours every day and two thirds $(66.5 \%)$ reported using alcohol for clean hands outside home, versus, slightly more than one half $(52.1 \%)$ reported wearing mask outside the home.

Figure (3): Distribution of the participants according to total score of their reported practices regarding COVID-19. It illustrates that half $(50.0 \%)$ of the participants had poor practices, 31.0 $\%$ of them had average practices, while who had good practices constituted only $19.0 \%$.

Table (4) Distribution of the studied participants according to their attitudes regarding COVID-19. It shows that less than three quarters $(72.4 \%, 74.7 \%, 70.2 \%$, $67.9 \% \& 72.2 \%$ ) respectively of the participants was agree that they and their family member have an increased chance of COVID-19 infection while they outside the home, it is difficult to control the infection during gatherings in public places, parks and events, the folk recipes are not useful in treating it, the country will succeed in controlling the spread of it and their is no risk in dealing with patients recovering from the COVID-19. Respectively. While more than three quarters $(78.3 \%, 76.0 \%, 79.7 \% \& 77.8 \%)$ respectively of them agreed that commitment to being at home and using preventive methods helping in preventing the spread of disease, COVID-19 infection is not a stigma, their is no dangers of 
dealing with the medical team working in the isolation hospitals after confirming they are negativity from COVID-19. And finally, there is no risk in dealing with returnees from abroad after the quarantine has ended. Versus, slightly more than three practices, total attitude towards COVID-19 and age, level of education, and family income.

The table reveals a statistically significant positive correlation was observed between total scores of knowledge, practice, attitude fifths $(62.9 \%)$ of the study participants agreed that there are no dangers of burying the deceased with the Corona virus in our graves.

Table (5): - Correlations of the studied participants' total knowledge, total and all socio-demographic characteristics of the study participants ( $\mathrm{p}$ value $=.0 .000$ ) Except, there is no a statistically significant correlation between total attitude scores and age as $(\mathrm{r}=0.035, \mathrm{p}$ value $=0.428)$. 
Table (1) Distribution of the studied participants according to their socio- demographic characteristics.

\begin{tabular}{|l|c|c|}
\hline \multicolumn{1}{|c|}{$\begin{array}{c}\text { Socio-demographic } \\
\text { Characteristics }\end{array}$} & \multicolumn{2}{c|}{ The studied participants } \\
(n=526)
\end{tabular}


Table (2) Distribution of the studied participants according to their knowledge regarding COVID-19.

\begin{tabular}{|c|c|c|c|c|c|c|}
\hline \multirow[b]{3}{*}{ COVID-19 knowledge } & \multicolumn{6}{|c|}{ The studied participants $(\mathrm{n}=526)$} \\
\hline & \multicolumn{2}{|c|}{ Yes } & \multicolumn{2}{|c|}{ No } & \multicolumn{2}{|c|}{ Don't know } \\
\hline & $\mathrm{N}$ & $\%$ & $\mathrm{~N}$ & $\%$ & $\mathrm{~N}$ & $\%$ \\
\hline Not previously diagnosed as a disease in humans & 225 & 42.8 & 116 & 22.1 & 185 & 35.2 \\
\hline \multirow{4}{*}{$\begin{array}{l}\text { Signs and symptoms } \\
-\quad \text { A very high temperature (fever) } \\
-\quad \text { A dry cough } \\
-\quad \text { Difficulty breathing or shortness of breath } \\
-\quad \text { General weakness }\end{array}$} & 472 & 89.7 & 5 & 1.0 & 49 & 9.3 \\
\hline & 465 & 88.4 & 5 & 1.0 & 56 & 10.6 \\
\hline & 469 & 89.2 & 3 & .6 & 54 & 10.3 \\
\hline & 442 & 84.0 & 14 & 2.7 & 70 & 13.3 \\
\hline \multirow{4}{*}{$\begin{array}{l}\text { Mode of transmission } \\
-\quad \text { Droplets from the patient during coughing or sneezing } \\
-\quad \text { Touching objects or surfaces contaminated with the virus } \\
-\quad \text { Direct contact with the infected person }\end{array}$} & & & & & & \\
\hline & 465 & 88.4 & 8 & 1.5 & 53 & 10.1 \\
\hline & 472 & 89.7 & 4 & .8 & 50 & 9.5 \\
\hline & 464 & 88.2 & 13 & 2.5 & 49 & 9.3 \\
\hline \multicolumn{7}{|l|}{ High risk groups } \\
\hline \multirow{3}{*}{$\begin{array}{ll}\text { - } & \text { People suffering from chronic diseases } \\
\text { (diabetes- heart- pressure). } & \\
\text { - } & \text { Pregnant women's } \\
\text { - } & \text { Elderly people }\end{array}$} & 449 & 85.4 & 6 & 1.1 & 71 & 13.5 \\
\hline & 405 & 77.0 & 16 & 3.0 & 105 & 20.0 \\
\hline & 460 & 87.5 & 6 & 1.1 & 60 & 11.4 \\
\hline \multirow{4}{*}{$\begin{array}{ll}\text { Treatment } \\
-\quad \text { No treatment presents } \\
-\quad \text { Isolation of patients } \\
-\quad \text { Isolation of contact }\end{array}$} & & & & & & \\
\hline & 398 & 75.7 & 27 & 5.1 & 101 & 19.2 \\
\hline & 465 & 88.4 & 4 & .8 & 57 & 10.8 \\
\hline & 453 & 86.1 & 5 & 1.0 & 68 & 12.9 \\
\hline
\end{tabular}

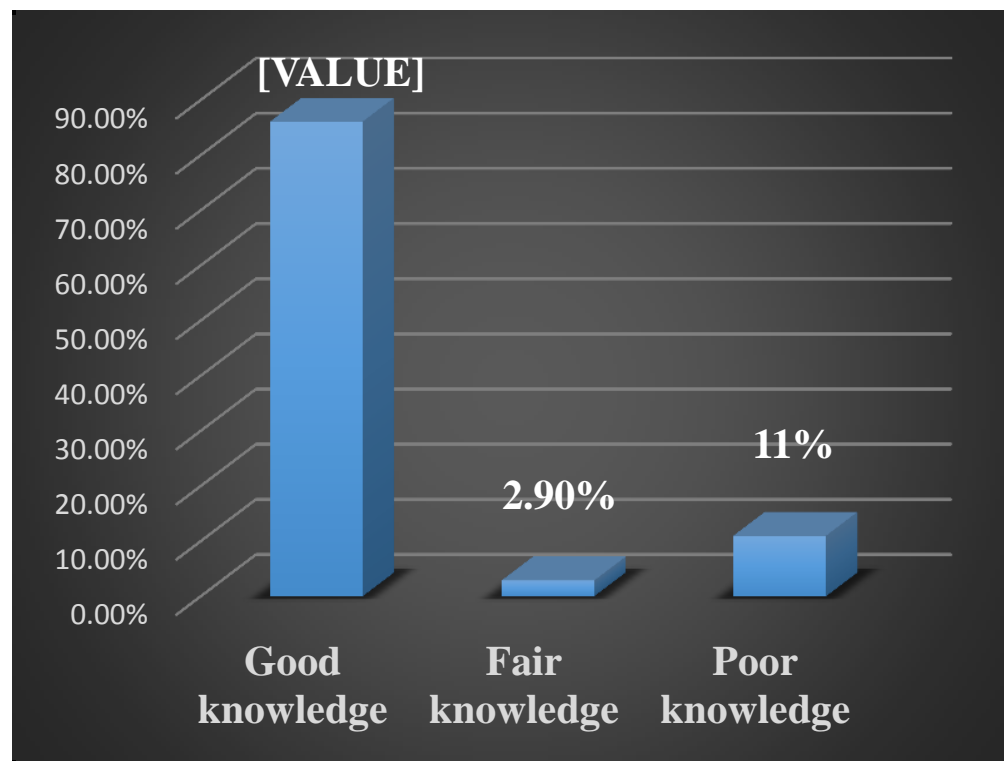


Figure (1): Distribution of the studied participants according to their total knowledge score regarding COVID-19.

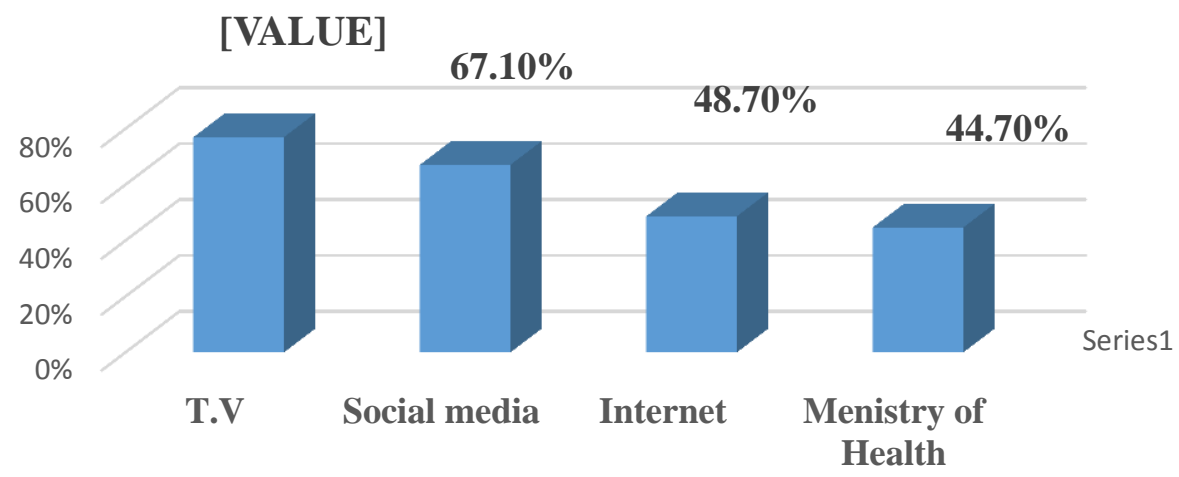

Figure (2): Distribution of the studied participants according to their various sources of information regarding COVID-19.

Table (3): Distribution of the studied participants according to their reported practices regarding COVID 19.

\begin{tabular}{|c|c|c|c|c|}
\hline \multirow[b]{3}{*}{ Reported preventive practices } & \multicolumn{4}{|c|}{$\begin{array}{l}\text { The studied participants } \\
\qquad(\mathrm{n}=526)\end{array}$} \\
\hline & \multicolumn{2}{|c|}{ Done } & \multicolumn{2}{|c|}{ Not done } \\
\hline & $\mathrm{N}$ & $\%$ & $\mathrm{~N}$ & $\%$ \\
\hline 1. Sit at home. & 417 & 79.3 & 109 & 20.7 \\
\hline $\begin{array}{l}\text { 2. Cover mouth and nose during } \\
\text { sneezing and cough }\end{array}$ & 441 & 83.8 & 85 & 16.2 \\
\hline 3. Wear mask outside the home & 274 & 52.1 & 252 & 47.9 \\
\hline $\begin{array}{l}\text { 4. Wash hands frequently for } 20 \\
\text { second }\end{array}$ & 458 & 87.1 & 68 & 12.9 \\
\hline 5. Avoidance overcrowded places. & 419 & 79.7 & 107 & 20.3 \\
\hline 6. Use alcohol for hands outside home & 350 & 66.5 & 176 & 33.5 \\
\hline 7. Disinfect surfaces inside the home & 461 & 87.6 & 65 & 12.4 \\
\hline 8. Eat fresh fruits and vegetables & 444 & 84.4 & 82 & 15.6 \\
\hline $\begin{array}{l}\text { 9. Drink plenty of water and warm } \\
\text { liquids }\end{array}$ & 426 & 81.0 & 100 & 19.0 \\
\hline 10. Sleep enough hours every day & 383 & 72.8 & 143 & 27.2 \\
\hline
\end{tabular}




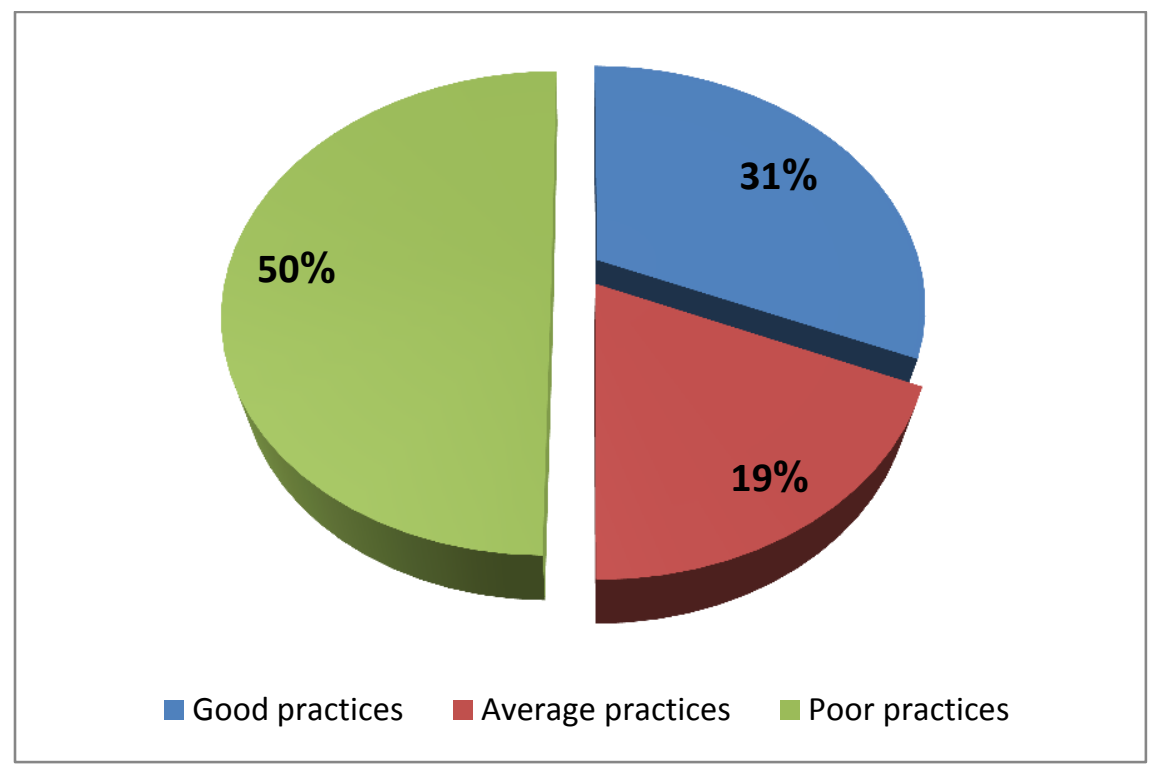

Figure (3): Distribution of the participants according to total score of their reported practices regarding COVID-19.

Table (4) Distribution of the studied participants according to their attitudes regarding COVID-19.

\begin{tabular}{|c|c|c|c|c|c|c|}
\hline \multirow[b]{3}{*}{ Attitude toward COVID-19 } & \multicolumn{6}{|c|}{$\begin{array}{l}\text { The studied participants } \\
(\mathbf{n}=\mathbf{5 2 6})\end{array}$} \\
\hline & \multicolumn{2}{|c|}{ Agree } & \multicolumn{2}{|c|}{ Uncertain } & \multicolumn{2}{|c|}{ Disagree } \\
\hline & $\mathrm{N}$ & $\%$ & $\mathrm{~N}$ & $\%$ & $\mathrm{~N}$ & $\%$ \\
\hline $\begin{array}{l}\text { 1- I and my family member have an increased } \\
\text { chance of infection while outside the home. }\end{array}$ & 381 & 72.4 & 90 & 17.1 & 55 & 10.5 \\
\hline $\begin{array}{l}\text { 2- It is difficult to control the infection during } \\
\text { gatherings in public places, parks and events. }\end{array}$ & 393 & 74.7 & 83 & 15.8 & 50 & 9.5 \\
\hline 3- The folk recipes are not useful in treating it. & 369 & 70.2 & 95 & 18.1 & 62 & 11.8 \\
\hline $\begin{array}{l}\text { 4- The country will succeed in controlling the } \\
\text { spread of it. }\end{array}$ & 357 & 67.9 & 140 & 26.6 & 29 & 5.5 \\
\hline $\begin{array}{l}\text { 5- Commitment to being at home and using } \\
\text { preventive methods helps prevent the spread of it. }\end{array}$ & 412 & 78.3 & 95 & 18.1 & 19 & 3.6 \\
\hline $\begin{array}{l}\text { 6- There is no risk in dealing with patients } \\
\text { recovering from the emerging coronavirus. }\end{array}$ & 380 & 72.2 & 84 & 16.0 & 62 & 11.8 \\
\hline 7- COVID-19 infection is not a stigma. & 400 & 76.0 & 74 & 14.1 & 52 & 9.9 \\
\hline $\begin{array}{l}\text { 8- There are no dangers of burying the deceased } \\
\text { with the Corona virus in our graves. }\end{array}$ & 331 & 62.9 & 145 & 27.6 & 50 & 9.5 \\
\hline $\begin{array}{l}\text { 9- There are no dangers of dealing with the medical } \\
\text { team working in the isolation hospitals after } \\
\text { confirming the negativity from COVID-19. }\end{array}$ & 419 & 79.7 & 63 & 12.0 & 44 & 8.4 \\
\hline $\begin{array}{l}\text { 10- There is no risk in dealing with returnees from } \\
\text { abroad after the quarantine has ended. }\end{array}$ & 409 & 77.8 & 80 & 15.2 & 37 & 7.0 \\
\hline
\end{tabular}


Table (5): - Correlations of the studied participants' total knowledge, total practices, total attitude and age, level of education, and family income.

\begin{tabular}{|c|c|c|c|c|c|c|}
\hline \multirow{2}{*}{ Items } & Practices & Knowledge & Attitude & Age & $\begin{array}{c}\text { Level of } \\
\text { education }\end{array}$ & $\begin{array}{c}\text { Family } \\
\text { income }\end{array}$ \\
\cline { 2 - 7 } & $\mathrm{r}$ & $\mathrm{r}$ & $\mathrm{r}$ & $\mathrm{r}$ & $\mathrm{r}$ & $\mathrm{r}$ \\
& $\mathrm{p}$ & $\mathrm{p}$ & $\mathrm{p}$ & $\mathrm{p}$ & $\mathrm{p}$ & $\mathrm{p}$ \\
\hline Practices & - & 0.705 & 0.372 & 0.087 & 0.548 & 0.354 \\
& & $0.000^{* *}$ & $0.000^{* *}$ & $0.046^{*}$ & $0.000^{* *}$ & $0.000^{* *}$ \\
\hline Knowledge & - & - & 0.380 & 0.125 & 0.589 & 0.359 \\
& & & $0.000^{* *}$ & $0.004^{* *}$ & $0.000^{* *}$ & $0.000^{* *}$ \\
\hline Attitude & 0.372 & 0.380 & - & 0.035 & 0.436 & 0.282 \\
& $0.000^{* *}$ & $0.000^{* *}$ & & 0.428 & $0.000^{* *}$ & $0.000^{* *}$ \\
\hline
\end{tabular}

**. Correlation is significant at the 0.01 level (2-tailed)

*. Correlation is significant at the 0.05 level (2-tailed). 


\section{Tanta Scientific Nursing Journal}

\section{Discussion}

The COVID-19 pandemic is a serious global health threat as reported by central for disease control and prevention (CDC) and WHO ${ }^{(19,20) .}$ The COVID-19 mortality rate of about $5.7 \%$ and had spread in more than 200 countries ${ }^{(21)}$. Egypt is considered one of the biggest countries in the Arab region, Africa and the Middle East. With more than 100 million population, of them $5,237,753$ population live in Gharbia governorate $^{(22)}$.

Epidemics and pandemics are a periodic phenomenon. People in the community face several challenges during such periods. Lack of knowledge often leads to an unconcerned attitude, which may adversely affect the preparedness to meet these challenges. Impacts of these epidemics and pandemics are often intense, which may adversely affect the behavior of people in the community (Rubin et al., 2009) (23). So, this study attempted to assess the knowledge, attitude and practices of public regarding COVID-19 in Al Gharbia Governorate, Egypt.

The researchers received responses from 526 participants, their age ranged from 20 58 years with mean $36.42 \pm 9.91$ years. More than half of them were female and married respectively, one third and more than one quarter had university and secondary\& technical education (Table 1).
The current study found that the total score most of the studied sample had good knowledge and only $11.0 \%$ of them had poor knowledge (figure 1). This may be related to the study was done during April and May Months which was the peak of outbreak of COVID-19 and all mass media, Facebook and internet as considered a main sources of information (Figure 2) that handled the disease that increase awareness of the public during this period. Nowadays the Facebook is the main social media platform in Egypt, and users of this platform increased from 33 million users in 2016 to more than 40 million in $2019^{(24)}$. The findings of the present study were in accordance with the study done by Hayat et al., (2020) ${ }^{(25)}$ and Lin et al., (2020) ${ }^{(26)}$, who mentioned that most of the participants had good (64.8\%) or average $(30.5 \%)$ COVID-19-related knowledge. On the contrary to our study, Nicholas et al., (2020) ${ }^{(27)}$, stated that that only $21.9 \%$ of the study population had a correct knowledge of the COVID-19 infection with a small fraction of the population approached knowing nothing about the disease.

As regards to specific knowledge of COVID-19, it showed that more than two fifths of the study participants stated that COVID-19 was not previously diagnosed as a disease in humans, versus more than 
one third $(35.2 \%)$ of them did not know. This conflict may be resulted as the disease don't appear in human before. Majority of participants in the present study had knowledge about signs and symptoms, mode of transmission, and also the majority of them knew that people suffering from chronic diseases as diabetes, heart diseases, blood pressure, pregnant women and elderly people were more susceptible to COVID-19 infection. Knowledge about the prevention and treatment was high among the participants, as three quarters stated that the infection of COVID-19 infection had no treatment, while most of them realized that it can be prevented by isolation of patients and contacts (Table 2). This in agreement with Al-Hanawi et al., (2020) ${ }^{(28)}$, who stated that most of the participants in their study (98\%) were aware of the clinical symptoms, and $96 \%$ knew that there is no clinically approved treatment for COVID19 as of the date of this manuscript. Also, Abdelhafiz et al., (2020) ${ }^{(29)}$, who showed that participants in their survey had good general knowledge about the disease, its methods of spread, and prevention.

The findings of our study reveal that there was a statistically significant positive correlation between total scores of knowledge with age, level of education, and family income of the participants
(Table 5) $(\mathrm{p}$ value $=.0 .000)$. These results are in consistence with Abdelhafiz et al., (2020) ${ }^{(29)}$ and Alahdal et al., (2020) ${ }^{(30)}$, who presented that in our participants, the mean knowledge score was significantly lower among older participants, those living in rural areas, with lower educational and monthly income levels. In study by Al-Hanawi et al., (2020) (28), there was significant predictors of participant knowledge in this study were age, gender, educational level, and income level.

Although most of the participants were knowledgeable about COVID-19, half of them had poor total practices score, $31.0 \%$ of them had average practices, while who had good practices constituted only $19.0 \%$ (figure 3). For specific preventive measures about COVID-19, the majority of participants reported that they staying at home, cover mouth and nose during sneezing and cough, washing hands frequently for 20 second, avoidance overcrowded places, disinfecting surfaces inside the home, eating fresh fruits and vegetables and drinking plenty of water and warm liquids. While, less than three quarters of them reported that enough sleep hours every day and two thirds reported using alcohol for clean hands outside home, versus, slightly more than one half reported wearing mask outside the home 
(Table 3). According to Honarvar et al., (2020) ${ }^{(31)}$, who found that nearly $70 \%$ of the people did the preventive measures to prevent the COVID-19, more than $80 \%$ of people washed their hands, and more than $60 \%$ used a face mask and removed it properly. However, nearly three-fourth of them had travel out of the city during two weeks before this study and more than half of them did not keep 1-m distance from others. Also, Reuben et al., (2020) ${ }^{(32)}$, who stated that most of the respondents in their study reportedly took different precautionary measures including social distancing, improved personal hygiene and use of face mask during the lockdown period. On the contrary to our research, study by Erfani et al., (2020) ${ }^{(33)}$, who mentioned that based on the overall practice score (89\%), most of the participants took precautions to avoid contamination by COVID-19. These could be primarily attributed to the vast broadcasting by the government and the good knowledge considering the high infectivity and easy transmission of COVID-19 virus through droplets. Unfortunately, the study still showed that $25 \%$ did not wear masks in public places and $9.6 \%$ didn't limit their commuting at the time of the outbreak. The current study revealed that there was a statistically significant positive correlation was observed between total score of practices with age, level of education, and family income of the participants (Table 5) (p value $=0.000)$. This in line with Alahdal et al., (2020) ${ }^{(30)}$, who showed that there was a significant difference in the practice score in different age groups. The better practice was observed amongst the 18-49 age group

Based on the results our study, participants showed a positive general attitude toward COVID-19 infection. Less than three quarters of the participants agreed that increasing chance of COVID-19 infection while they outside the home, difficulty to control the infection during gatherings in public places, parks and events, the folk recipes are not useful in treating it, the country succeed in controlling the spread of it and there is no risk in dealing with patients recovering from the COVID-19. According to Honarvar et al., (2020) ${ }^{(31)}$, who mentioned in their study, less than half of the people considered themselves at risk of COVID-19 and were worried about it, while a higher proportion were concerned about their family's health. In the same consequence Egyptian government take some measures of in order to minimize the crowdedness and prevent the spread of infection through enforcing a nighttime curfew for some months and all people should wear face 
masks outside home and in public places. Also, the decision included the closure of all restaurants and cafes for the same period.

In the current study more than three quarters of them agreed that commitment to being at home and using preventive methods helping in prevent the spread of disease. According to study by Erfani et al., (2020) ${ }^{(33)}$, who stated that majority of participants agreed with having quarantine, locking down cities, restricting travel, and closing educational centers and religious cites $(96 \%, 96.8 \%, 99.3 \%$, and $98.5 \%$, respectively). Zhong et al., (2020) ${ }^{(34)}$, who said although attitudes towards COVID-19 were optimistic, most residents took precautions to prevent infection by COVID-19: not going to crowded places and wearing masks when going outside. These strict preventive practices could be primarily attributed to the very strict prevention and control measures implemented by local governments such as banning public gatherings. Also, the present study showed that more than three quarters of them agreed that COVID-19 infection is not a stigma. According to Abdelhafiz et al., (2020) (29), who illustrated that about $23 \%$ of participants thought the infection of the virus is associated with stigma. Although the number is limited, we think that it has significance, since it may lead to underreporting of cases, which may cause rapid spread of the disease. Also, Mak et al., (2020) (35), stated that fear and stigmatization may impact the intentions of an infected individual to seek medical assistance in the right timing which might contribute to increased morbidity and mortality.

Also, our results revealed that more than three quarters of them agreed that there aren't dangers of dealing with the medical team working in the isolation hospitals after confirming they are negativity from COVID-19. And finally, the present study reveals that the participants stated that there is no risk in dealing with returnees from abroad after the quarantine has ended. Versus, slightly more than three fifth $(62.9 \%)$ of the study participants agreed that there are no dangers of burying the deceased with the Corona virus in our graves. This positive attitude may be related to continuous announcement and reports of Ministry of Health through different mass media regarding the dealing with medical staff or patient after the confirming of negative infection from COVID-19. Also, safe burying the deceased with the Corona virus in our graves through following the correct rules to avoid any harms to the people. Finally, the current study illustrates that there was a 
statistically significant positive correlation was observed between total scores of knowledge, practice, and attitude of the participants of COVID-19 (Table 5) (p =. 0.000). This finding agrees with Reuben et al., (2020) ${ }^{(32)}$, who showed a significant ( $\mathrm{p}<0.05)$ relationship existing between good knowledge of COVID-19 amongst residents of north-central Nigeria and positive attitude towards COVID-19. Also, the study by Hanawi et al., (2020) ${ }^{(28)}$, who stated that the participants' high knowledge of COVID-19 translates into good and safe practices, during the COVID-19 pandemic, which suggests that the practices of Saudi residents are very cautious.

\section{Conclusion and recommendations}

Based on the finding of this study we can concluded that in spite of the majority of respondents have exhibited good knowledge and positive attitude they reported poor practices regarding preventive measures during COVID-19 pandemic. So, we recommended that: -

- Communicate rapidly and effectively to residents in COVID-19 areas about importance of following preventive measures.

- Use mobile technologies to educate publics regarding signs, symptoms and transmission routes and preventive measures.
- Monitoring of contacts of patients with COVID-19 to ensure access to testing and treatment for those who develop signs and symptoms.

\section{References}

1. Shivalingesh Krishnappa Kamate1, A,B,E,F, Swati Sharma2,A,C,E, Sahil Thakar2,B,D, Divya Srivastava 1,A,C,E, Kaushikee Sengupta2,B,C, Ahmed Jhurry Hadi3,B,D,E, Alankrita Chaudhary2,B,F, Ruby Joshi4,B,E, Kuldeep Dhanker2,B,C,F. Assessing Knowledge, Attitudes and Practices of dental practitioners regarding the COVID-19 pandemic: A multinational study.Dent Med Probl. 2020;57 (1):11-170.

2. Zhu N, Zhang D, Wang W, Li X, Yang B, Song J, et al. A novel coronavirus from patients with pneumonia in China, 2019. N Engl J Med, 2020;382(8): 727-733. https:// doi.org/10.1056/NEJMoa2001017

3. World Health Organization. Coronavirus disease (COVID-19) Weekly Epidemiological Update. Available: https://www.who.int/ $\underline{\text { docs/default-source/coronaviruse/ }}$ situation-reports/20200914-weeklyepi-update-5.pdf?sfvrsn=cf929d04_2

4. Statistics of COVID-19 in Egypt. https://www.worldometers.info/corona virus/country/egypt/ 
5. Li, J. Y., You, Z., Wang, Q., et al. (2020). The epidemic of 2019-novelcoronavirus (2019-nCoV) pneumonia and insights for emerging infectious diseases in the future. Microbes and Infection,22(2), 80-85.

6. Riou J, Althaus CL. Pattern of early human-to-human transmission of Wuhan 2019 novel coronavirus (2019nCoV), December 2019 to January 2020. Eurosurveillance. (2020) 25:2000058 doi: 10.2807/15607917.ES.2020.25.4.2000058

7. Chan JF-W, Yuan S, Kok K-H, To $\mathrm{KK}-\mathrm{W}$, Chu $\mathrm{H}$, Yang J, et al. A familial cluster of pneumonia associated with the 2019 novel coronavirus indicating person-toperson transmission: a study of a family cluster. Lancet. (2020) 395:514-23. doi: 10.1016/S01406736(20)30154-9.

8. Huang C. Clinical features of patients infected with 2019 novel coronavirus in Wuhan, China. Lancet 2020, 395, 497-506. [CrossRef]. https://doi.org/ 10.1016/S0140-6736(20)30183-5

PMID: 31986264

9. World Health Organization. Modes of transmission of virus causing COVID19: implications for IPC precaution recommendations. 29 March 2020.
10. Cao Z. Estimating the elective reproduction number of $2019-\mathrm{nCoV}$ in China. medRxiv 2020. [CrossRef].

11. Guo, Y. R., Cao, Q. D., Hong, Z. S., et al. (2020). The origin, transmission and clinical therapies on coronavirus disease 2019 (COVID-19) outbreak an update on the status. Military Medical Research, 7(1), 11.

12. Vermund S, Collins C. Remembering America's global connections in the time of coronavirus, 2020. Available: https://www.thinkglobalhealth.org/arti cle/remembering-americasglobalconnections-time-coronavirus

13. Ballard, Madeleine, et al. "Prioritising the role of community health workers in the COVID-19 response." BMJ Global Health 5.6 (2020): e002550.

14. Community Nursing and the COVID19 Pandemic Available at: https://www.qnis.org.uk/communitynursing-and-the-covid-19-pandemic/

15. Egypt statistics, Central agency for public mobilization and statistics available at : https://www. capmas.gov.eg/

16. Raosoft sample size calculator available at: http://www.raosoft. com/samplesize.html

17. Azlan AA, Hamzah MR, Sern TJ, Ayub SH, Mohamad E (2020) Public 
knowledge, attitudes and practices towards COVID-19: A cross-sectional study in Malaysia. PLoS ONE 15(5): e0233668. $\quad$ https://doi.org/10.1371/ journal.pone. 0233668

18. Taber KS. The Use of Cronbach's Alpha When Developing and Reporting Research Instruments in Science Education. Research in Science Education. 2018; 48: 1273-96

19. Central for disease control and prevention. Global COVID-19 available at: $\underline{w w . c d c . g o v /}$ coronavirus/2019-ncov/global-covid19/index.html.

20. WHO Director-General's opening remarks at the media briefing on COVID-19 11 March 2020. Retrieved April 4, 2020, from https ://www.who.int/dg/speec hes/detai 1/who-direc tor-gener al-s-openi ngremar ks-at-the-media -briefi ng-oncovid -19-11-March -2020).

21. Baudk, D., Qi, X., Nielsen-Saines, K., et al. (2020). Real estimates of mortality following COVID-19 infection. The Lancet Infectious Diseases. https ://doi.org/10.1016/ $\underline{S 1473-3099(20) 30195-X .}$

22. The Central Agency for Public Mobilization and Statistics Website (2020). Retrieved July 14, 2020, from
https://www.capmas.gov.eg/Pages/pop ulationClock.aspx

23. Rubin, G.J., Amlôt, R., Page, L., Wessely, S., 2009. Public perceptions, anxiety, and behaviour change in relation to the swine flu outbreak: Cross sectional telephone survey. BMJ 339, 156. https://doi.org/10.1136/ bmj.b2651

24. Facebook users in Egypt in Febraury (2019). Retrieved April4, 2020, from https ://napol eonca t.com/stats /faceb ook-users -inegypt/2019/02.

25. Hayat K, Rosenthal M, Xu, Arshed M, Li, Zhai P, Kassa GD, Fang Y View of Pakistani Residents toward Coronavirus Disease (COVID-19) during a Rapid Outbreak: A Rapid Online Survey. International Journal of Environmental Research and Public Health. 2020, 17, 3347; doi:10.3390/ijerph17103347

26. Lin $\mathrm{Y}, \mathrm{Hu} \mathrm{Z}$, Alias $\mathrm{H}$ and Wong LP. Knowledge, Attitudes, Impact, and Anxiety Regarding COVID-19 Infection Among the Public in China. 2020; 8:236. doi: 10.3389/fpubh.2020.00236

27. Nicholas T, Mandaah FV, Esemu SN, Vanessa AB, Gilchrist KT, Vanessa LF, Shey ND. COVID-19 knowledge, attitudes and practices in a conflict 
affected area of the South West Region of Cameroon. Pan Africa Medical Journal. 2020;35(2):34. DOI: 10.11604/pamj.2020.35.2.22963.

28. Al-Hanawi MK, Angawi K, Alshareef N, Qattan AMN, Helmy HZ, Abudawood Y, Alqurashi M, Kattan WM, Kadasah NA, Chirwa GC, Alsharqi O. Knowledge, Attitude and Practice TowardCOVID-19 Among the Public in the Kingdom of Saudi Arabia: A Cross-Sectional Study. Front. Public Health. 2020; 8:217.

doi: 10.3389/fpubh.2020.00217

29. Abdelhafiz A, Mohammed Z, Ibrahim M E, Ziady HH, Alorabi M, Ayyad M, Sultan A E. Knowledge, Perceptions, and Attitude of Egyptians Towards the Novel Coronavirus Disease (COVID-19). Journal of Community Health.2020.https://doi.org/10.1007/s1 0900-020-00827-7

30. Alahdal H, Basingab F, Alotaibi R. An analytical study on the awareness, attitude and practice during theCOVID-19 pandemic in Riyadh, Saudi Arabia. Journal of Infection and Public Health. 2020. https://doi.org/10.1016/j.jiph.2020.06.015

31. Honarvar B, Lankarani K B, Kharmandar A Shaygani F, Zahedroozgar M, Haghighi, MR,Ghahramani S, Honarvar H, Daryabadi MM, Salavati Z, Hashemi SM, Joulaei H, Zare M. Knowledge, attitudes, risk perceptions, and practices of adults toward COVID-19: a population and field-based study from Iran. International Journal of Public Health.2020. https://doi.org/10. 1007/s00038-020-01406-2.

32. Reuben RC, Danladi MM, Saleh DA, Ejembi PE. Knowledge, Attitudes and Practices Towards COVID-19: An Epidemiological Survey in North-Central Nigeria. Journal of Community Health.2020. https://doi.org/10.1007/s10900-02000881-1

33. Erfani A, Shahriarirad R, Ranjbar K, Mirahmadizadeh A \& Moghadami M. Knowledge, Attitude and Practice toward the Novel Coronavirus (COVID-19) Outbreak: A PopulationBased Survey in Iran. [Preprint]. Bull World Health Organ. E-pub: 30 March 2020.doi:http://dx.doi.org/10.2471/BL T.20.256651

34. Zhong B, Luo W, Li H, Zhang Q, Liu X, Li W, Li Y. Knowledge, attitudes, and practices towards COVID-19 among Chinese residents during the rapid rise period of the COVID-19 outbreak: a quick online crosssectional survey. International Journal of Biological Sciences. 2020; 16(10): 1745-1752. doi: 10.7150/ijbs.45221

35. Mak WW, Cheung F, Woo J, Lee D, Li P, Chan KS, et al. A comparative study of the stigma associated with infectious diseases (SARS, AIDS, TB). Hong Kong Med J. (2009) 15:34-7. 